\title{
SOCIO-MEDICAL ASPECTS OF DEPRESSION AMONG ELDERLY ADULTS IN SERBIA
}

Svetlana Radevic ${ }^{1}$, Nela Djonovic ${ }^{2,3}$, Natasa Mihailovic ${ }^{3}$, Ivana Simic Vukomanovic ${ }^{1,3}$, Katarina Janicijevic ${ }^{1}$, Marija Sekulic ${ }^{2}$ and Sanja Kocic S $^{1,3}$

${ }^{1}$ Department of Social medicine, Faculty of Medical Sciences, University of Kragujevac, Kragujevac, Serbia

${ }^{2}$ Department of Hygiene and ecology, Faculty of Medical Sciences, University of Kragujevac, Kragujevac, Serbia

${ }^{3}$ Institute of Public Health of Kragujevac, Kragujevac, Serbia

\section{SOCIJALNO-MEDICINSKI ASPEKTI DEPRESIJE KOD STARIH OSOBA U SRBIJI}

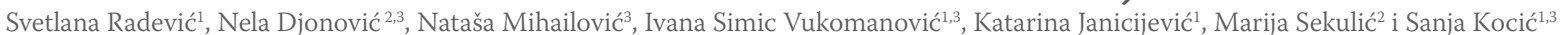

${ }^{1}$ Univerzitet u Kragujevcu, Fakultet medicinskih nauka, Katedra za Socijalnu medicinu, Kragujevac, Srbija

${ }^{2}$ Univerzitet u Kragujevcu, Fakultet medicinskih nauka, Katedra za Higijenu i ekologiju, Kragujevac, Srbija

${ }^{3}$ Institut za javno zdravlje Kragujevac, Kragujevac, Serbia

\begin{abstract}
Depression is the most frequent mental health problem in older age with serious consequences on personal, interpersonal and social level. The aim of this study was to determine the association of demographic factors, socio-economic factors and health status characteristics, with the presence of depressive symptoms in the elderly persons. The survey was conducted as a part of the national study "Health Survey of the Serbian population" in 2013. Data on the population aged 65 years and over were used for the purposes of this study (3540 respondents). PHQ-8 questionnaire was used to assess the presence of symptoms of depression. The relations between the presence of depressive symptoms, as a dependent variable, and a set of independent variables was examined by univariate and multivariate logistic regressions. Depression (PHQ-8 score $\geq 10$ ) was registered in 10\% of the population aged 65 and above, wherein it was statistically significantly higher in women (12.7\%) than in men (6.5\%). Limitations in performing of daily activities showed to be the strongest predictor of depression in the elderly, while respondents who have had serious limitations had even six times more chanse to develop depression $(O R=6.84)$. Respondents who rated their health as "bad or very bad" for $49.5 \%$ more frequently manifested depressive symptoms compared to those who evaluated their health as "very good or good" $(\mathrm{OR}=3.49)$. Respondents who have had two or more chronic diseases were three times more likely to have depression $(O R=3.1)$ compared to people without chronic disease.
\end{abstract}

Keywords: depression, elderly adults, risk factors, national health survey

\section{SAŽETAK}

Depresija je jedan od najčešcich problema mentalnog zdravlja u starijoj životnoj dobi sa ozbiljnim posledicama na ličnom, meduljudskom i društvenom nivou. Ciljovog istraživanja je bio da se utvrdi povezanost demografskih, socio-ekonomskih faktora $i$ karakteristik zdravstvenog stanja sa prisustvom depresivnih simptoma kod starih osoba. Istraživanje je sprovedeno kao deo nacionalne studije "Istraživanje zdravlja stanovništva Srbije" 2013. godine. Za potrebe ove studije korišćeni su podaci o populaciji starijih od 65 godina. Za procenu prisustva simptoma depresije je korišćen PHQ8 upitnik. Povezanost prisustva depresivnih simptoma, kao zavisne varijable i skupa nezavisnih varijabli ispitivana je univarijantnom $i$ multivarijantnom logističkom regresijom. Depresija (PHQ-8 skor $\geq 10$ ) je registrovana kod 10\% stanovništva starosti 65 i više godina pri čemu je statistički značajno bila veća kod žena (12.7\%) u odnosu na muškarce (6.5\%). Kao najjaci prediktor pojave depresije kod starijih osoba, kada je u pitanju zdravstveno stanje izdvaja se ograničenost u obavljanju svakodnevnih aktivnosti, pa su ispitanici koji su imali ozbiljna ograničenja imali čak šest puta veću šansu za pojavu depresije $(O R=6.84)$. Ispiatnici koji su svoje zdravlje ocenili kao "loše ili veoma loše" su za 49.5\% češće ispoljavali depresivne simptome u poredenju sa onima koji svoje zdravlje ocenjuju kao "veoma dobro ili dobro" $(O R=3.49)$. Ispitanici koji su imali dve ili vise hroničnih bolesti su imali tri puta veću šansu da imaju depresiju $(O R=3.1)$ u odnosu na osobe bez hroničnih bolesti.

Ključne reči: depresija, stare osobe, faktori rizika, nacionalno istraživannje zdravlja 


\section{INTRODUCTION}

Depression is the most frequent mental health problem in older age (1) with serious consequences on personal, interpersonal and social level (2). At least one in ten people aged 65 or more have significant symptoms of depression (3). Depressive disorders significantly impair quality of life and social functioning in diseased person, increasing overall morbidity and disability (4), causing significant social and economic consequences (5), threatening primarily women (6) and persons of lower socioeconomic status (7). It is also an independent predictor of mortality and is the leading cause of suicide in elderly adults, which is present in approximately $85 \%$ of elderly adults who have died by suicide (2).

Depression results from a complex interaction of genetic, biological, physiological and social factors (8). Changes characteristic for an old age and meny stressful events that occur more often in older age, such as chronical medical conditions, physical or cognitive functional decline, limited mobility, loss of independence, retirement, financial difficulties, isolation, death of a spouse or friend, loss of social support, contribute to the worsening of life perspective and depression $(9,10)$. Most authors consider that risk factors simultaneously affect a person's vulnerability for the development of depression, and that this vulnerability varies depending on the interaction between some factors, as well as on the life circumstances of each individual (11). Depression often occurs in conjunction with other mental disorders and physical illnesses and is often undiagnosed and untreated, because it is considered that the depression is common and natural reaction to the changes that older age brings $(9,12)$.

The global burden of depression is on the rise, which is mainly attributed to the aging of the population and to the growing number of people with physical and mental diseases which are often accompanied by depressive disorders. If current trend continues, according to the WHO estimations, by the year of 2030 depressive disorders are going to become the leading diagnostic category among the causes of disease burden worldwide, primarily in middle and higher income countries (13).

The aim of this study was to determine the association of demographic factors, socio-economic factors and health status characteristics, with the presence of depressive symptoms in the elderly persons.

\section{METHODS}

\section{Study population and sample}

The survey was conducted as a part of the national study "Health Survey of the Serbian population" in 2013, by mass interviewing a random, representative sample of the population of Serbia. The survey was conducted according to the model of cross-sectional study in the Republic of
Serbia and it did not include the population living on the territory of Kosovo and Metohija. The target population did not include persons living in collective households and institutions. The survey was conducted in accordance with the methodology and instruments of the European Health Survey - Second Wave (European Health Interview Survey - EHIS wave 2) (14). It was implemented by the Ministry of Health of the Republic of Serbia.

The sample consisted of all households listed in all enumeration areas in census conducted in 2011. The mechanism used to obtain the random sampling of the respondents and households was a combination of two sampling techniques: stratification and a multi-stage sampling. A stratified two-stage sample of the population of the Republic of Serbia has been chosen in such a way to provide a statistically reliable assessment of the indicators that indicate the health status of the population at the national level, as well as at the level of 4 geographic areas (Vojvodina, Belgrade, Shumadija and Western Serbia, Southern and Eastern Serbia) identified as the main strata in the sample. Their further division into urban and rural areas resulted in a total of 8 strata. In the first stage, a total of 670 enumeration areas was selected. The households were the units of the second stage. Within each enumeration area, 10 addresses were selected ( +3 spare addresses) inhabited by households to be interviewed. Out of total 10,089 households contacted, 6500 of them agreed to participate in the survey, so that the response rate of households was $64.4 \%$. Of the total of 16,474 registered household members aged 15 years and over, 14,623 of them agreed to be interviewed, giving a response rate of $88.9 \%$. Out of this number of people who agreed to be interviewed, 13,756 of them accepted to fill in the questionnaire (response rate $94.1 \%$ ). Data on the population aged 65 years and over were used for the purposes of this study (3540 respondents).

\section{Instruments}

The questionnaires constructed in accordance with the questionnaire created by the European health research- the second wave (wave EHIS 2) (14), defined by internationally accepted indicators and adapted to the particularities of the area, were used as the instruments in this research (15).

To assess the presence of symptoms of depression, a Patient Health Questionnaire-8 (PHQ-8 questionnaire) containing eight questions which relate to the following physical problems was used: a reduction of interest or of feeling of pleasure in performing the activities; discouragement, melancholy, hopelessness; sleep problems (trouble falling asleep, sleeping in a continuity or too much sleep); a feeling of fatigue or lack of energy; reduced or increased appetite; feeling bad about themselves, feeling of failure, disappointment of themselves or of their families (feeling of worthlessness or of excessive or inappropriate guilt); difficulties with concentration during the activities such as reading a newspaper or television viewing (decreased ability to think or to concentrate, or ambiguities - estimated 
subjectively or by others); slowed movement or speech, or otherwise, psychomotor restlessness that caused that they were moving more than usual (observed by others, and not just a subjective feeling).

Based on questions from the PHQ-8 questionnaire, respondents answered how often they were bothered by any of these mental health problems during the previous two weeks. Possible answers were "not at all", "a few days", "more than 7 days" and "almost every day". Responses to each question were evaluated using the score of 0 ("not at all"), 1 ("a few days"), 2 ("more than 7 days") and 3 ("almost every day"), and after gathering points for each answer, the total score obtained the values that ranged from 0 to 24 . The score values 0 to 4 indicate the absence of symptoms of depression, a score of 5 to 9 denotes mild depressive symptoms (subsyndromal depression), and values close to 10 and more clearly indicate a high probability of the existence of a depressive episode (depression), which is further qualified as moderate (score 10 to 14), moderately severe (score 15 to 19) and severe depressive episodes (score of 20 and above). Based on the value of the 8-PHQ score, the patients were divided into one of the 3 categories: no symptoms of depression, depressive symptoms are mild (subsyndromal depression) and a depressive episode (depression) (16).

Following variables were used in the study: demographics (gender, age, marital status and type of settlement), socio-economic (education level, employment status and financial status), diverse dimensions of health (self-assessment of health, limitations in activities of daily living (ADL), chronic diseases and presence of pain) and social support.

Social support score (Oslo-3 Social Support Scale) was formed on the basis of three questions from the questionnaire and assigning a certain number of points for each answer: "How many people are so close to you that you can count on them when you have serious personal problems?" (Points ranging from 1 ("None") to 4 ( "6 or more")), "How many people are really interested in you, in what you are doing, or in what is going on in your life?" (scores ranging from 1 ("not interested at all") to 5 ("very interested")), "How easy is for you to get practical help from neighbors if you have a need for it?" (The number of points ranges from 1 ("very difficult") to 5 ("very easy")). After collecting points, the scores of social support were formed: a strong social support (12-14 points), moderate (9-11 points) and bad (3-8 points) (17).

\section{Statistical analysis}

All the data of interest were presented and analyzed by adequate mathematical-statistical methods appropriate for the data type. The Chi-square test was used to compare proportions between groups. The t-test was used to compare continuous variables between groups. All the results where the probability is less than $5 \%$ are considered to be statistically significant. The relations between the presence of depressive symptoms, as a dependent variable, and a set of independent variables was examined by univariate and multivariate logistic regressions. Univariate logistic regression models were used to examine the associations between potential factors and the depressive symptoms. Variables that were statistically significant $(\mathrm{p}<0.05)$ were further examined in multivariable logistic regressions. The unadjusted odds ratios (ORs) with their corresponding 95\% confidence intervals (CIs) were also obtained. All statistical calculations were performed using commercial, standard software package SPSS, version 18.0. (The Statistical Package for Social Sciences software (SPSS Inc, version 18.0, Chicago, IL)).

\section{RESULTS}

Depression (PHQ-8 score $\geq 10$ ) was registered in 10\% of the population aged 65 and above, wherein it was statistically significantly higher in women $(12.7 \%)$ than in men (6.5\%) $\left(x^{2}=95.294, p<0,001\right)$. In relation to the subcategories of depression, largest percentage of respondents had moderate depressive episode (5.8\%), and severe depression was detected in $1.6 \%$ of the respondents. Mild depressive symptoms (subsyndromal depression) were present in every fifth women (21.2\%) and every eighth man (12.7\%). The average value of the 8-PHQ score was 3.5 and it was statistically significantly higher among women (4.1) than in men (2.6) $(\mathrm{t}=-10.493, \mathrm{p}<0,001)$ (Table 1$)$.

Among the subjects who have had major depressive episode, every second had moderate depressive episode

Table 1. Prevalence of depression in the population aged 65 and over by gender

\begin{tabular}{|c|c|c|c|c|c|c|c|}
\hline \multirow{2}{*}{ PHQ-8 scor } & \multicolumn{2}{|c|}{ Females } & \multicolumn{2}{|c|}{ Males } & \multicolumn{2}{|c|}{ Total } & \multirow{2}{*}{$\mathbf{p}$} \\
\hline & $\mathbf{n}$ & $\%$ & $\mathbf{n}$ & $\%$ & $\mathbf{n}$ & $\%$ & \\
\hline 0-4 (none depressive) & 1330 & 66.1 & 1235 & 80.8 & 2656 & 72.5 & \\
\hline 5-9 (mild depresive) & 427 & 21.2 & 194 & 12.7 & 621 & 17.5 & $<0.001$ \\
\hline 10-24 (depressive episode) & 255 & 12.7 & 99 & 6.5 & 354 & 10.0 & \\
\hline 10-14 (moderate) & 149 & 7.4 & 56 & 3.7 & 205 & 5.8 & \\
\hline 15-19 (moderately severe) & 65 & 3.2 & 28 & 1.8 & 93 & 2.6 & \\
\hline 20-24 (severe) & 41 & 2.1 & 15 & 1.0 & 56 & 1.6 & \\
\hline Average value of score & \multicolumn{2}{|c|}{2.6} & \multicolumn{2}{|c|}{4.1} & \multicolumn{2}{|c|}{3.5} & $<0.001$ \\
\hline
\end{tabular}




\begin{tabular}{|c|c|c|c|c|c|c|c|}
\hline \multirow[t]{2}{*}{ PHQ-8 scor } & \multicolumn{2}{|c|}{$\begin{array}{c}\text { No symptoms of } \\
\text { depression }\end{array}$} & \multicolumn{2}{|c|}{$\begin{array}{c}\text { Moderate symptoms of } \\
\text { depression }\end{array}$} & \multicolumn{2}{|c|}{ Depressive episode } & \multirow[t]{2}{*}{$\mathrm{p}^{*}$} \\
\hline & $\mathrm{n}$ & $\%$ & $\mathrm{n}$ & $\%$ & $\mathrm{n}$ & $\%$ & \\
\hline \multicolumn{8}{|l|}{ Age (years) } \\
\hline $65-74$ & 1501 & 76.8 & 315 & 16.1 & 139 & 7.1 & \multirow{3}{*}{$<0.001$} \\
\hline $75-84$ & 945 & 68.2 & 271 & 19.6 & 169 & 12.2 & \\
\hline $85+$ & 119 & 59.5 & 35 & 17.5 & 46 & 23.0 & \\
\hline \multicolumn{8}{|l|}{ Marital status } \\
\hline Single & 26 & 60.5 & 9 & 20.9 & 8 & 18.6 & \multirow{4}{*}{$<0.001$} \\
\hline Married & 1521 & 72.4 & 309 & 15.7 & 135 & 6.9 & \\
\hline Widowed & 943 & 66.2 & 284 & 19.9 & 198 & 13.9 & \\
\hline Separated/Divorced & 75 & 70.1 & 19 & 17.8 & 13 & 12.1 & \\
\hline \multicolumn{8}{|l|}{ Education } \\
\hline Elementary school or lower & 1269 & 64.9 & 425 & 21.7 & 262 & 13.4 & \multirow{3}{*}{$<0.001$} \\
\hline Middle school & 881 & 79.8 & 154 & 13.9 & 69 & 6.3 & \\
\hline High school/College or higher & 415 & 86.5 & 42 & 8.8 & 23 & 4.8 & \\
\hline \multicolumn{8}{|l|}{ Employment status } \\
\hline employed & 229 & 59.8 & 105 & 27.4 & 49 & 12.8 & \multirow{3}{*}{$<0.001$} \\
\hline unemployed & 68 & 67.3 & 16 & 15.8 & 17 & 16.8 & \\
\hline inactive & 2268 & 74.2 & 500 & 16.4 & 288 & 9.4 & \\
\hline \multicolumn{8}{|l|}{ Well-being index } \\
\hline Poor class & 1321 & 66.9 & 409 & 20.7 & 245 & 12.4 & \multirow{3}{*}{$<0.001$} \\
\hline Middle class & 469 & 74.3 & 104 & 16.5 & 58 & 9.2 & \\
\hline Rich class & 757 & 83 & 108 & 11.6 & 51 & 5.5 & \\
\hline \multicolumn{8}{|l|}{ Place of residence } \\
\hline Urban & 1471 & 77.3 & 283 & 14.9 & 149 & 7.8 & \multirow{2}{*}{$<0.001$} \\
\hline Rural & 1094 & 66.8 & 338 & 20.6 & 205 & 12.5 & \\
\hline \multicolumn{8}{|l|}{ Social support } \\
\hline strong & 25 & 80.6 & 3 & 9.7 & 3 & 9.7 & \multirow{3}{*}{$<0.001$} \\
\hline moderate & 291 & 61.8 & 96 & 20.4 & 84 & 17.8 & \\
\hline poor & 1849 & 60.8 & 522 & 18.2 & 667 & 21.9 & \\
\hline
\end{tabular}

* Chi-square test

(57.9\%), $26.3 \%$ had a moderately severe, and $15.8 \%$ had severe depressive episode, with no statistically significant differences between genders. In patients with depressive episode, the most common symptoms that lasted more than seven days, or were present almost every day, were a feeling of fatigue or lack of energy (90.7\%), sleep problems (75.7\%), feelings of discouragement and hopelessness (66.5\%).

The prevalence of depression continuously increases with age and it was highest among respondents aged 85 and over (23\%), which is three times higher prevalence in relation to the age group of $65-74$ years $(7.1 \%)\left(x^{2}=75.44\right.$, $\mathrm{p}<0.001)$. In terms of marital status, the results showed that the lowest percentage of depression was among respondents who were married or cohabiting (6.9\%). The highest number of depressed persons was among those who have never been married or cohabiting (18.6\%) $\left(\mathrm{x}^{2}=68.49, \mathrm{p}<0.001\right)$. In the relation to the education degree, the prevalence of depressive episodes was the highest in the category of the least educated persons (13.4\%), and every forth respondent with primary or lower level of education $(21.7 \%)$ had mild depressive symptoms $\left(x^{2}=136,61\right.$, $\mathrm{p}<0.001)$. Between the well-being index and the prevalence of depression, there was an inverse association, so the percentage of depressed patients was the highest among the poor $(12.4 \%)\left(\chi^{2}=84.84, \mathrm{p}<0.001\right)$. When it comes to a place of residence, a significantly higher percentage of subjects with depression is present in the rural areas (12.5\%), compared to the urban areas $(7.8 \%)\left(\mathrm{x}^{2}=49.43, \mathrm{p}<0.001\right)$. Among respondents who have had a strong social support, more than $90 \%$ of them didn't have symptoms of depression, while among those with a low score of social support every fifth respondent was depressed $(21.9 \%)\left(\chi^{2}=50.05\right.$, $\mathrm{p}<0.001)$ (Table 2).

There was a statistically significant correlation between the self-assessment of health status and the presence of the depressive symptoms $\left(x^{2}=713.08, p<0.001\right)$. Among respondents who rated their health as "bad or very bad", there was significantly higher percentage of those who had depressive episode (21.8\%), compared to those who evaluated their health as "very good or good" $(0.4 \%)$.

The presence of depression symptoms is significantly different relative to the degree of limitation in the performance of daily activities $\left(x^{2}=621.54, p<0.001\right)$. More than one third of patients with severe constraints on performing of daily activities (36.8\%) had a major depressive episode, while only $1.7 \%$ of the subjects without limitations, manifested depressive episode. More than a quarter of subjects with severe or very severe pain in the previous four weeks had depressive symptoms (27.5\%), while 
Table 3. Prevalence of depression and health status of the respondents

\begin{tabular}{|c|c|c|c|c|c|c|c|}
\hline \multirow[t]{2}{*}{ PHQ-8 scor } & \multicolumn{2}{|c|}{$\begin{array}{c}\text { No symptoms of } \\
\text { depression }\end{array}$} & \multicolumn{2}{|c|}{$\begin{array}{c}\text { Moderate symptoms of } \\
\text { depression }\end{array}$} & \multicolumn{2}{|c|}{ Depressive episode } & \multirow[t]{2}{*}{$\mathrm{p}^{*}$} \\
\hline & $\mathrm{n}$ & $\%$ & $\mathrm{n}$ & $\%$ & $\mathrm{n}$ & $\%$ & \\
\hline \multicolumn{8}{|l|}{ Self-assessment of health } \\
\hline good & 747 & 94.6 & 40 & 5.1 & 3 & 0.4 & \multirow{3}{*}{$<0.001$} \\
\hline moderate & 1123 & 84.2 & 168 & 12.6 & 43 & 3.2 & \\
\hline poor & 695 & 49.1 & 413 & 29.2 & 308 & 21.8 & \\
\hline \multicolumn{8}{|l|}{ Limitations in everyday activities } \\
\hline no limitations & 1843 & 88.9 & 196 & 9.5 & 35 & 1.7 & \multirow{3}{*}{$<0.001$} \\
\hline limited, but not serious & 603 & 55.9 & 335 & 31.1 & 140 & 13.0 & \\
\hline seriously limited & 42 & 36.8 & 30 & 26.3 & 42 & 36.8 & \\
\hline \multicolumn{8}{|l|}{ The presence of bodily pain } \\
\hline didn't have a pain & 1079 & 90.7 & 84 & 7.1 & 26 & 2.2 & \multirow{4}{*}{$<0.001$} \\
\hline weak pain & 546 & 79.5 & 105 & 15.3 & 36 & 5.2 & \\
\hline moderate pain & 578 & 22.5 & 216 & 34.8 & 73 & 20.6 & \\
\hline strong and very strong pain & 362 & 45.4 & 216 & 27.1 & 219 & 27.5 & \\
\hline \multicolumn{8}{|l|}{ The impact of pain on daily activities } \\
\hline not at all & 214 & 87 & 25 & 10.2 & 7 & 2.8 & \multirow{3}{*}{$<0.001$} \\
\hline lightly and moderate & 980 & 71.2 & 306 & 22.2 & 90 & 6.5 & \\
\hline high and very high & 292 & 40.1 & 206 & 28.3 & 231 & 31.7 & \\
\hline \multicolumn{8}{|l|}{ Chronic diseases / conditions } \\
\hline no chronic diseases & 390 & 93.3 & 20 & 4.8 & 8 & 1.9 & \multirow{3}{*}{$<0.001$} \\
\hline have one chronic disease & 601 & 89.7 & 51 & 7.6 & 18 & 2.7 & \\
\hline have two or more chronic diseases & 1574 & 64.2 & 550 & 22.4 & 328 & 13.4 & \\
\hline
\end{tabular}

"Chi-square test

Table 4. Odds ratios (OR) and 95\% confidence intervals (CI) for the depression depending on demographics and socioeconomic characteristics

\begin{tabular}{|c|c|c|c|c|}
\hline & \multirow{2}{*}{$\begin{array}{c}\text { Univariate model } \\
\text { OR }(95 \% \mathrm{CI})\end{array}$} & \multicolumn{3}{|c|}{ Multivariate model } \\
\hline & & $\mathrm{p}$ & $\mathrm{OR}(95 \% \mathrm{CI})$ & $\mathrm{p}$ \\
\hline \multicolumn{5}{|l|}{ Gender } \\
\hline male & 1 & & 1 & \\
\hline female & $2.161(1.847-2.530)$ & $<0,001$ & $1.678(1.395-2.018)$ & $<0,001$ \\
\hline \multicolumn{5}{|l|}{ Age groups } \\
\hline $65-74$ & 1 & & 1 & \\
\hline $75-84$ & $1.539(1.319-1.796)$ & $<0,001$ & $1.373(1.164-1.621)$ & $<0,001$ \\
\hline $85+$ & $2.250(1.665-3.041)$ & $<0,001$ & $1.728(1.250-2.389)$ & $<0,001$ \\
\hline \multicolumn{5}{|l|}{ Marital status } \\
\hline married / common-law marriage & 1 & & 1 & \\
\hline never married / common-law marriage & $2.24(1.204-4.165)$ & $<0,001$ & $2.023(1.056-3.879)$ & 0.034 \\
\hline widower / widow & $1.751(1.503-2.039)$ & $<0,001$ & $1.287(1.077-1.538)$ & 0.006 \\
\hline divorced & $1.462(0.954-2.240)$ & $<0,001$ & $1.433(0.916-2.239)$ & 0.115 \\
\hline \multicolumn{5}{|l|}{ Settlement type } \\
\hline city & 1 & & 1 & \\
\hline other & $1.690(1.457-1.961)$ & $<0,001$ & $1.255(1.045-1.506)$ & 0.015 \\
\hline \multicolumn{5}{|l|}{ Education } \\
\hline high and senior high school & 1 & & 1 & \\
\hline high school & $1.616(1.197-2.181)$ & $<0,001$ & $1.366(1.002-1.862)$ & 0.048 \\
\hline primary school and lower & $3.456(2.619-4.562)$ & $<0,001$ & $1.886(1.379-2.580)$ & $<0,001$ \\
\hline \multicolumn{5}{|l|}{ Wellbeing Index } \\
\hline rich class & 1 & & & \\
\hline middle class & $1.684(1.315-2.155)$ & $<0,0005$ & $1.433(1.105-1.858)$ & 0.07 \\
\hline poor class & $2.413(1.986-2.932)$ & $<0,0005$ & $1.607(1.272-2.033)$ & $<0,001$ \\
\hline \multicolumn{5}{|l|}{ Social support } \\
\hline strong & 1 & & 1 & \\
\hline moderate & $1.725(1.215-2.541)$ & & $1.523(1.051-2.264)$ & $<0,001$ \\
\hline poor & $3.749(2.428-5.845)$ & & $3.045(1.984-4.829)$ & $<0,001$ \\
\hline
\end{tabular}


Table 5. Odds ratios (OR) and 95\% confidence intervals (CI) for the depression depending on health caracteristics

\begin{tabular}{|c|c|c|c|c|}
\hline & \multicolumn{2}{|l|}{ Univariate model } & \multicolumn{2}{|l|}{ Multivariate model } \\
\hline & OR $(95 \% \mathrm{CI})$ & $\mathrm{p}$ & OR(95\%CI) & $\mathrm{p}$ \\
\hline \multicolumn{5}{|l|}{ Self-assessment of health } \\
\hline good & 1 & & 1 & \\
\hline average & $3.264(2.322-4.589)$ & $<0,001$ & $1.561(1.010-2.411)$ & 0.045 \\
\hline poor & $18.022(13.027-24.932)$ & $<0,001$ & $3.495(2.276-5.365)$ & $<0,001$ \\
\hline \multicolumn{5}{|l|}{ Limitations in everyday activities } \\
\hline no limitations & 1 & & 1 & \\
\hline limited, but not serious & $6.285(5.238-7.540)$ & $<0,001$ & $2.995(2.389-3.756)$ & $<0,001$ \\
\hline seriously limited & $13.867(9.268-20.760)$ & $<0,001$ & $6.846(4.047-11.582)$ & $<0,001$ \\
\hline \multicolumn{5}{|l|}{ Chronic diseases / conditions } \\
\hline no chronic diseases & 1 & & & \\
\hline have one chronic disease & $1.599(1.012-2.526)$ & 0.449 & $1.499(0.743-3.026)$ & 0.258 \\
\hline have two or more chronic diseases & $7.770(5.249-11.501)$ & $<0,001$ & $3.109(1.640-5.891)$ & 0.001 \\
\hline \multicolumn{5}{|l|}{ The presence of bodily pain } \\
\hline didn't have a pain & 1 & & & \\
\hline weak / moderate pain & $3.756(2.995-4.702)$ & $<0,001$ & $1.276(0.957-1.700)$ & 0.046 \\
\hline strong and very strong pain & $11.787(9.266-14.995)$ & $<0,001$ & $3.710(1.619-5.826)$ & 0.001 \\
\hline \multicolumn{5}{|c|}{ The impact of pain on daily activities } \\
\hline not at all & 1 & & 1 & \\
\hline lightly and moderate & $2.702(1.831-3.989)$ & $<0,001$ & $1.614(0.978-2.663)$ & 0.061 \\
\hline high and very high & $10.008(6.709-14.930)$ & $<0,001$ & $1.319(0.863-2.015)$ & 0.201 \\
\hline
\end{tabular}

\section{DISCUSSION}

among respondents with no presence of pain, depression was present in only $2.2 \%\left(\chi^{2}=622.55, \mathrm{p}<0.001\right)$. Research also confirmed an association between the presence of chronic diseases and depression $\left(\chi^{2}=276.64, \mathrm{p}<0.001\right)$, subjects who had two or more of chronic diseases (multimorbidity) were seven times more likely to have a depression (13.4\%), as compared to those without chronic diseases (1.9\%) (Table 3).

All demographic and socio-economic variables were analyzed using the multivariate model. Results of the study showed that women $(\mathrm{OR}=1.68)$ and persons aged 85 years or more $(\mathrm{OR}=1.72)$ are 1.7 times more likely to be depressed in relation to the men and respondents aged 65-74 years. Also, a life without a partner $(\mathrm{OR}=2.02)$, the lowest level of education $(\mathrm{OR}=1.89)$ and poverty $(\mathrm{OR}=1.61)$, proved to be significant predictors of depression. A chance for the presence of depression was three times higher in people with poor social support $(\mathrm{OR}=3.04)$ (Table 4).

Limitations in performing of daily activities, when it comes to health status of respondents, showed to be the strongest predictor of depression in the elderly, while respondents who have had serious limitations had even six times more chanse to develop depression $(\mathrm{OR}=6.85)$. Respondents who rated their health as "bad or very bad" for $49.5 \%$ more frequently manifested depressive symptoms compared to those who evaluated their health as "very good or good" $(\mathrm{OR}=3.49)$. Respondents who have had two or more chronic diseases were three times more likely to have depression $(\mathrm{OR}=3.11)$ compared to people without chronic disease, while those with chronic pain were for $71 \%$ more likely to express depressive symptoms $(\mathrm{OR}=3.71)$ (Table 5).
Among citizens of Serbia aged 65 years and over, 17.5\% of respondents had mild depressive symptoms, and a depressive episode was registered in $10 \%$ of the population. The average prevalence of depression in elderly adults varies between $10.0 \%$ and $15.0 \%$ (18), while some countries report significantly higher rates of prevalence. In Brazil, the prevalence of depression was $30.6 \%$ (1), while Cahoon reported that depression affects an estimated $15 \%$ to $19 \%$ of Americans age 65 and older (19). Large variations between countries concerning the prevalence of depression can be explained by socio-demographic and cultural differences, as well as by differences in the methodological approach to data collecting (1).

The prevalence of depression in our sample continuously increases with age and it has the highest values in the category of 85 years of age and over (23\%). Studies suggest that people age 65 and older have twice the chance to develop a depression in comparison to younger adult population, as well as that an older age is the predictor of depression (20), and that the prevalence of depression is the highest in the population of the oldest persons (21).

The number of women reporting the depression symptoms is twice as high as the number of men (12.7\% : 6.5\%), which is in accordance with the results from the available literature that are supporting the fact that women are at greater risk to develop a depression $(6,22,23)$. Gender difference in the prevalence of depression is explained by a number of factors (genetic, biological, psychological), as well as by a different social roles and status of women in society (24). Studies showed that the increased risk of depression in women, at least partly, is attributable to negative attitude towards them, to the lack of appreciation for their work, to fewer op- 
portunities for education and employment and to a greater risk of domestic violence (25). The fact that men often do not recognize their symptoms of depression, as depression is generally considered as a "women's disease", should be taken into account in interpreting the differences in the prevalence of depression between women and men (26). Women are more open and willing to express the symptoms they feel, verbally as well as behaviorally, they more often complain of psychosomatic ailments and emotional instability, which is why they more frequently use the health care services (1). Power and health are traditionall masculine values and that is why men often avoid to express their emotions that are typical for females, and this may contribute to masking of depression (27).

The results of our study showed an association between depression and marital status. The smallest number of depressive was detected among respondents who were married or cohabiting, while multivariate regression model identified the best chance to develop a depression among people who have never been married/cohabiting $(\mathrm{OR}=2.02)$. Depressive simptoms are more common among persons who were either never married or who were previously married and currently have no partner, compared with married people (22). Yan et al. conducted a quantitative meta-analysis of the association between depression and marital status in people over the age of 55, based on 24 cross-sectional studies and eight longitudinal studies. Compared to married elderly people, unmarried elderly people $(\mathrm{OR}=1.55)$, widowed $(\mathrm{OR}=1.49)$ and never-married people $(\mathrm{OR}=1.32)$ had a higher risk for depression (28).

Empirical studies conducted in the past few decades showed that people who are married have a series of physical and mental benefits, achieve greater functionality, have better subjective assessmment of their health condition, have lower rates of morbidity and live longer than individuals who are not married (29). Married people have the advantage in terms of financial resources and stability, social and psychological support, as well as a support in choosing a healthy lifestyle (30).

The association between depression and socio-economic status was confirmed by the results of our study, where it was found that individuals with the lowest level of education $(\mathrm{OR}=1.88)$ and those belonging to the class of poor $(\mathrm{OR}=1.61)$ are significantly more likely to develop the symptoms of depression. Several studies confirm a strong inverse relationship between SES and depression (31,32). In a prospective cohort study, Koster and associates analyzed the correlation between depression and socio-economic status. The level of education and financial income at 2593 respondents aged $55-85$ years were observed as indicators of socio-economic status. The obtained results showed that the persons of lower socioeconomic status have had a $50 \%$ greater chance of being depressed in comparison with those belonging to the highest SES group (33). Studies show that the lack of income and inability to satisfy the daily needs, along with the emotional stress due to an uncertain future, are significant predictors of depression
(34). On the other hand, a higher level of education provides a better job and higher social status, better developed social networks and adopting healthy lifestyle habits (better access to informations). Better educated people have higher levels of health literacy, healthier lifestyle, better use of available informations in dealing with everyday problems that could negatively affect their health (35).

When it comes to a social support, among respondents who have a strong social support over $90 \%$ of them do not have symptoms of depression, while among those with poor social support every fourth respondent has a mild depressive symptoms or depressive episode, which is in accordance with results from the literature that indicate a strong relationship of depression and social support (36, 37). Good social support network increases the self-esteem of the individual and the resistance to the occurrence of negative emotions and depressive symptoms (38).

Poor physical health, functional disability, and chronic pain are proven to be a significant predictor of depression (18), but on the other hand, depression worsens outcomes of physical illness (39). As expected, our results showed that people who have two or more chronic diseases have three times higher risk of being depressed ( $O R=3.109$ ), while people who have serious limitations in performing daily activities have almost seven times greater risk of depression ( $\mathrm{OR}=6.846)$. Many epidemiological studies indicate a high comorbidity of depression and other psychiatric disorders, somatic symptoms and physical ailments, especially in population of the oldest persons $(40,41)$. Large 14-center, cross-national study conducted in nine western European countries, whose aim was to test an association between physical health and depressive symptoms of patients older than 65 years, showed that the association of depressive symptoms with functional disability was stronger than the one with chronic physical conditions (42).

\section{CONCLUSION}

Identification of risk factors associated with the development of depression in elderly, early diagnosis and timely, adequate and effective treatment and management of depression, are crucial factors to reduce the serious consequences to which these disorders can lead the individual, their families and the community as a whole. Mental health of older people can be improved through the promotion of active and healthy aging, which means creating the conditions and environment that support the well-being and enable people to live a healthy and integrated lifestyle.

\section{ACKNOWLEDGMENTS}

The study is a part of the 2013 National Health Survey for the population of Serbia carried out by the Ministry of Health of the Republic of Serbia and professional support of the Institute of Public Health of Serbia 'Dr Milan Jovanovic Batut'. 


\section{REFERENCES}

1. Nogueira EL, Rubin LL, Giacobbo Sde S, Gomes I, Cataldo Neto A. Screening for depressive symptoms in older adults in the Family Health Strategy, Porto Alegre, Brazil. Rev Saude Publica 2014;48(3):368-77.

2. Fiske A, Loebach Wetherell J, Gatz M Depression in Older Adults. Annu Rev Clin Psychol 2009;5:363-389.

3. Neno R, Aveyard B, Heath H. Older People and Mental Health Nursing: A Handbook of Care. Oxford: Blackwell Publishing; 2007.

4. Dines Ph, Hu W, Sajatovic M. Depression in later-life: an overview of assessment and management. Psychiatria Danubina 2014;26(Suppl. 1):78-84.

5. McLaughlin KA. The Public Health Impact of Major Depression: A Call for Interdisciplinary Prevention Efforts. Prev Sci. 2011;12(4):361-71.

6. Jeon GS, Jang SN, Rhee SJ, Kawachi I, Cho SI. Gender Differences in Correlates of Mental Health Among Elderly Koreans. Journal of Gerontology: SOCIAL SCIENCES 2007;62(5):323-329.

7. Fryers T, Melzer D, Jenkins R. Social inequalities and the common mental disorders: a systematic review of the evidence. Soc Psychiatry Psychiatr Epidemiol 2003;38(5):229-37.

8. Blazer DG. Depression in late life: review and commentary. J Gerontol A Biol Sci Med Sci 2003;58(3):249-65.

9. Cole MG, Dendukuri N. Risk factors for depression among elderly community subjects: a systematic review and meta-analysis. Am J Psychiatry 2003;160(6):114756.

10. Musić Milanović S, Erjavec K, Poljičanin T, Vrabec B, Brečić. Prevalence of depression symptoms and associated socio-demographic factors in primary health care patients. Psychiatr Danub 2015;27(1):31-7.

11. National Collaborating Centre for Mental Health. The NICE Guideline on the Treatment and Management of Depression in Adults. Updated Edition. London: The British Psychological Society and The Royal College of Psychiatrists; 2010.

12. Jacobi F, Rosi S, Faravelli C, Goodwin R, ArbabzadehBouchez S, Lepine JP. The Epidemiology of Mood Disorders. In Griez EJL, Faravelli C, Nutt DJ, Zohar J, editors. Mood Disorders: Clinical Management and Research Issues. Chichester: John Wiley \& Sons Ltd.; 2005.

13. World Health Organization. The Global Burden of Disease: 2004 update. Geneva: World Health Organization; 2008.

14. Eurostat. European Health Interview Survey (EHIS wave 2) Methodological manual, 2013 Edition. Luxembourg: Publications Office of the European Union; 2013.

15. Institute of Public Health of Serbia. Results of the National Health Survey in Serbia, 2013. Belgrade: Institute of Public Health of Serbia; 2014.

16. Kroenke K, Strine TW, Spitzer RL, Williams JB, Berry JT, Mokdad AH. The PHQ-8 as a measure of current depression in the general population. J Affect Disord 2009;114(1-3):163-73.
17. Bøen H, Dalgard OS, Bjertness E. The importance of social support in the associations between psychological distress and somatic health problems and socioeconomic factors among older adults living at home: a cross sectional study. BMC Geriatr 2012;12:27.

18. Buber I, Engelhardt H. The Association between Age and Depressive Symptoms among Older Men and Women in Europe. Findings from SHARE. Comparative Population Studies 2011; 36(1):103-126.

19. Cahoon CG. Depression in Older Adults. American Journal of Nursing 2012;112(11):22-30.

20. Rancans E, Vrublevska J, Snikere S, Koroleva I, Trapencieris M. The point prevalence of depression and associated sociodemographic correlates in the general population of Latvia. J Affect Disord 2014;156:104-10.

21. Nicolosi GT, Falcao DVdS, Batistoni SST, Lopes A, Cachioni M, Neri AL, Yassuda MS. Depressive symptoms in old age: relations among sociodemographic and self-reported health variables. Int Psychogeriatr 2011;23(6):941-9.

22. Rodda J, Walker Z, Carter J. Depression in older adults. BMJ 2011;343:d521

23. Jia $H$, Lubetkin EI. Incremental decreases in quality-adjusted life years (QALY) associated with higher levels of depressive symptoms for U.S. Adults aged 65 years and older. Health Qual Life Outcomes 2017;15(1):9.

24. World Health Organization. The World Health Report 2001. Mental Health: New Understanding, New Hope. Geneva: World Health Organization; 2001.

25. Afifi M. Gender differences in mental health. Singapore Med J 2007;48(5):385.

26. Magovcevic M, Addis ME. Linking gender-role conflict to nonnormative and self-stigmatizing perceptions of alcohol abuse and depression. Psychol Men Masc 2005;6(2):127-36.

27. Alvarado BE, Zunzunegui MV, Béland F, Sicotte M, Tellechea L. Social and gender inequalities in depressive symptoms among urban older adults of latin america and the Caribbean. J Gerontol B Psychol Sci Soc Sci 2007;62(4):226-36.

28. Yan XY, Huang SM, Huang CQ, Wu WH, Qin Y. Marital status and risk for late life depression: a meta-analysis of the published literature. J Int Med Res 2011;39(4):1142-54.

29. Koball HL, Moiduddin E, Henderson J, Goesling B, Besculides $M$. What Do We know about the link between marriage and health? J Fam Issues 2010;31(8):1019-40.

30. Perkins JM, Lee HY, James KS, Oh J, Krishna A, Heo J, Lee JK, Subramanian SV. Marital status, widowhood duration, gender and health outcomes: a cross-sectional study among older adults in India. BMC Public Health 2016;16(1):1032.

31. Johnson-Lawrence V, Kaplan G, Galea S. Socio-economic patterning in adulthood and depressive symptoms among a community sample of older adults in the United States. Public Health 2015;129(5):594-6. 
32. Freeman A, Tyrovolas S, Koyanagi A, Chatterji S, Leonardi M, Ayuso-Mateos JL, Tobiasz-Adamczyk B, Koskinen S, Rummel-Kluge C, Haro JM. The role of socio-economic status in depression: results from the COURAGE (aging survey in Europe). BMC Public Health. 2016;16(1):1098.

33. Koster A, Bosmaa H, Kempena G, Penninxb B, Beekmanb A, Deegc D, Eijk J. Socioeconomic differences in incident depression in older adults: The role of psychosocial factors, physical health status, and behavioral factors. Journal of Psychosomatic Research 2006;6:619-627.

34. Lorant V, Deliege D, Eaton W, Robert A, Philippot P, Ansseau M. Socioeconomic inequalities in depression: a meta-analysis. Am J Epidemiol 2003;157(2): 98-112.

35. Von dem Knesebeck O, Geyer S. Emotional support, education and self-rated health in 22 European countries. BMC Public Health 2007;7:272.

36. SangNam A, Seonghoon K, Hongmei Z. Changes in Depressive Symptoms among Older Adults with Multiple Chronic Conditions: Role of Positive and Negative Social Support. Int. J. Environ. Res. Public Health 2017;14:16.

37. Wang X, Cai L, Qian J, Peng J. Social support moderates stress effects on depression. Int J Ment Health Syst 2014;8(1):41.
38. Lee C, Dickson DA, Conley CS, Holmback GN. A closer look at self-esteem, perceived social support, and coping strategy: a prospective study of depressive symptomatology across to transition to college. J Soc Clin Psychol 2014;33(6):560-85.

39. Cho HJ, Lavretsky H, Olmstead R, Levin M, Oxman MN, Irwin MR. Prior depression history and deterioration of physical health in community-dwelling older adults-a prospective cohort study. Am J Geriatr Psychiatry 2010;18(5):442-51.

40. Egede LE. Major depression in individuals with chronic medical disorders. Prevalence, and correlates and association of health resource utilization, lost productivity and functional disability. Gen Hosp Psychiatry. 2007;29(5):409-16.

41. Gunn JM, Ayton DR, Densley K, Pallant JF, Chondros $\mathrm{P}$, Herrman HE, et al. The association between chronic illness, multimorbidity and depressive symptoms in an Australian primary care cohort. Soc Psychiatry Psychiatr Epidemiol 2012;47(2):175-84.

42. Braam AW, Prince MJ, Beekman AT, Delespaul P, Dewey ME, Geerlings SW, et al. Physical health and depressive symptoms in older Europeans. Results from EURODEP. Br J Psychiatry 2005;187(1):35-42. 